\title{
LONDON'S BURNING: STRUCTURALIST READINGS OF THE URBAN INFERNO IN THE 1950'S BRITISH LITERATURE OF MULTI-CULTURALISM
}

\author{
Tadd Graham Fernée \\ New Bulgarian University, Sofia, Bulgaria
}

\begin{abstract}
This article examines a literary triangle treating a modern re-imagining of the Dantean Inferno in Caribbean migrant experience. Sam Selvon's The Lonely Londoners advanced a stylistic and intellectual revolution in post-World War II British literature, inspiring Colin MacInnes' Absolute Beginners in the founding literary texts of contemporary British multi-cultural society. It followed the template of Jean Rhys Voyage in the Dark. We must read these complex texts to understand the conflicted multi-cultural society that Britain has become today: they deal with identity and solidarity, atomisation and commodification, Empire and capitalism, while throwing light on the most recent advances in historical and theoretical scholarship by pioneers such as Olivette Otele and Reni Eddo-Lodge. Moreover, these texts throw new light on unanswered Structuralist and Post-Structuralist debates from Emile Durkheim to Martin Heidegger. This article examines the intersectionality of class, gender and race within both the national British framework of post-war capitalism and the wider colonial heritage of slavery and forced labour, highlighting voices who articulated an ideal of multi-cultural humanism that remains crucial today.
\end{abstract}

Keywords: Windrush generation, post-colonial literature, Sam Selvon, Ian MacInnes, Jean Rhys, Structuralism, Black history, gender, multi-culturalism, British Literature, Dante, capitalism, Caribbean literature, cultural studies, Stuart Hall

\section{Article history:}

Received: 27 November 2020;

Reviewed:17 December 2020;

Accepted: 18 December 2020;

Published: 21 December 2020

Copyright (C) 2020 Tadd Graham Fernée

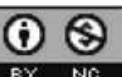

This open access article is published and distributed under a CC BY-NC 4.0 International License which permits non-commercial use, distribution, and reproduction in any medium, provided the original author and source are credited. Permissions beyond the scope of this license may be available at tfernee@hotmail.com. If you want to use the work commercially, you must first get the authors' permission.

Citation: Fernée, T.G. (2020). London's Burning: Structuralist Readings of the Urban Inferno in the 1950's British Literature of Multi-culturalism. English Studies at NBU, 6(2), 265-294.

https://doi.org/10.33919/esnbu.20.2.6

Tadd Graham Fernée is part of the Department of Foreign Languages and Cultures of New Bulgarian University. He is a researcher for New York University, and the author of The Enlightenment and Violence: Modernity and Nation-Making (2014).

E-mail: tfernee@hotmail.com

https://orcid.org/0000-0003-4364-3463 


\section{Sam Selvon, the Windrush generation, and Structuralism}

Sam Selvon travelled from Trinidad to Britain in April 1950, keen to succeed as a writer in the metropolis in the same year as V.S. Naipaul and George Lamming: "There were adverts everywhere: 'Come to the Mother Country! The Mother Country needs you!' (Wills, 2017, pp.13, 6). Citizens of the United Kingdom - a legal identity enshrined in the 1948 British Nationality Act - they were "regarded as strangers" (Wills, 2017, p. 8). Until the immigration rules were changed in 1962, “all Britain's imperial subjects and citizens of the commonwealth - a staggering quarter of the population of the planet had the legal right to live in Britain as British citizens" (Wills, 2017, p. 4). Selvon's experimental novel the Lonely Londoners (1956) was a self-conscious milestone in English literature: "I was the first Caribbean writer to explore and employ dialect in a full-length novel where it was used in both narrative and dialogue". Selvon had tried "to recapture a certain quality in West Indian everyday life" (Jordison, 2018, p. 1). Everydayness invokes Edmund Husserl's "lifeworld" problem: texture, quality and intimacy beyond quantified abstraction. Susheila Nasta captures Selvon's depiction of the London lifeworld as a process of "giving voice to early migrant experience":

...we accompany Moses, a veteran black Londoner on his routine journey to welcome yet another newcomer into the fold ... the tragicomic urban theatre of [Selvon's] fictional world [is] a labyrinthine city [where] his cast of rootless, unlettered characters soon learn to survive and reinvent [the city] (Nasta, 2018, p. 1).

Nasta writes that Selvon's "reinvention" deconstructively "exploded some of the narrow and hyphenated categories by which black working-class voices had hitherto been defined", a means "to not only reinvent London but to reshape its spaces giving his previously voiceless characters a place to live in it" (Nasta, 2018, p. 2). Reinvention of place implies identity as a production, not the discovery of a pre-existing monolith. Selvon's Windrush contemporary, Cultural Studies pioneer Stuart Hall, has articulated the identity premise underpinning Selvon's depiction of the making of roots:

Identity is not as transparent or unproblematic as we think. Perhaps instead of thinking of identity as an already accomplished fact, which the new cultural practices then represent, we should think, instead, of identity as a 'production' which is never complete, always in process, and always constituted within, not outside, representation (Rutherford, 1990, p. 222). 
Selvon is called the "father of black writing" in Britain for his experimental novel, "a key figure in the literary re-imagining of Britain during the post-war years" (Nasta, 2018, p. 2). Selvon described his methodological experiment thus: "I had difficulty starting the novel in straight English ... I had written the narrative in English and most of the dialogues in dialect. Then I started both narrative and dialogue in dialect and the novel just shot along" (Jordison, 2018, p. 1). He suggests that encasing 'linguistic dialect' (dialogue) within the 'official language' (narrative) is a distancing of the lifeworld through the false objectivity of the official language, which is really a political construct. We note that Louis Ferdinand Celine had done this in French using the "dialect" of working class Paris suburbia in Journey to the End of the Night (1932).

Selvon wrote: "I experimented with the language as it is used by Caribbean people. I found a chord, it was like music, and I sat like a passenger in a bus and let the language do the writing". Selvon seemingly renounces authorship in favour of language itself. We are reminded of Foucault's claim that the "Will to Knowledge" crushes "naïve knowledges beneath scientificity" (Foucault, 1980, pp. 78-81). He called for the "death of the author". Through the dispersal of the "episteme" of "Man", Foucault predicted a "rebirth of language" (Foucault, 1966, p. 395). Foucault hearkened back to the "6th century Greek poets [who] had spoken true discourse," inspiring "respect and terror", "meting out justice", and "weaving into the fabric of fate" (Foucault, 1997, p. xii). Yet, Selvon made no such claim to cultural authenticity in poetic language, stating that it "may be called artificial and fabricated" (Jordison, 2018, p. 2). Again, Hall's writings on 'identity' are helpful: “This view [of identity] problematises the very authority and authenticity to which the term, 'cultural identity', lays claim" (Rutherford, 1990, p. 222). Selvon's language experiment therefore presents a conundrum. He neither celebrated the Heideggerian language mysticism of Foucault (a bid for a 'new' spiritual authority) nor the authentic language of the street (a crude populism), as did Celine. What, then, was Selvon doing in revolutionizing the meanings of 'Englishness', 'whiteness', or 'blackness' in The Lonely Londoners?

The key partly lies in interpretations of Selvon's work. Sam Jordison locates Selvon's experiment as the culmination of early $20^{\text {th }}$ century European modernist (read: 'white') literature. In overcoming the distance imposed by official English upon the 
Caribbean lifeworld, Selvon simultaneously removes the distance between white British readers and their black British counterparts in a political act: "Any white readers who picked up the book when it was first published in 1956 with strong ideas about the otherness of West Indian people would find these assumptions challenged. As Selvon himself said, he had found a way of 'extending the language'”. Selvon's 'extension', by Jordison's account, differs from Foucault's yielding to the occluded cultural power in language. Rather, Selvon consciously bends the modernist tradition to his will driven by democratic political engagement:

From his very first sentence referencing T.S. Eliot and Dickens he was taking on the masters of English prose ... Like James Joyce before him (and the intimate interiority of much of Selvon's prose is clearly influenced by the great Irish writer), he owns colonial language and bends it to his will. He presents English back to us, new and repurposed (Jordison, 2018, p. 2).

Jordison argues implicitly that the English language has been bent into a specific shape by what Hall calls "the traumatic character of 'the colonial experience'”. Hall writes: "The ways in which black people, black experiences, were positioned and subjected in the dominant regimes of representation were the effects of a critical exercise of cultural power and normalisation ... They had the power to make us see and experience ourselves as 'Other'” (Rutherford, 1990, p. 225). Selvon's stylistic revolution was in triggering the "Creolization" of English Literature (Nasta, 2018, p. 2).

When Helon Habila explores the politics of The Lonely Londoners, we might see it in this light:

The novel ... is set in 1950s London and concerns the group of Caribbean immigrants known as the 'Windrush' generation, who arrived on the SS Windrush in 1948.A lot of them had fought for Britain in the Second World War and, having found that they couldn't settle back into their small island communities, decided to seek better opportunities in the 'mother country'. Welcomed at first by the British as a source of cheap labour, by the late 50s, as their numbers grew, they became the target of racial hatred and xenophobia, and even hasty anti-immigration legislation in parliament ... The Lonely Londoners was the first novel to take on the task of representing this unrepresented group (Habila, 2007, p. 1). 
For Habila, the political core of the novel is in representation, or replacing an absence with a presence in post-war British civil society. This absence/presence poses the "white privilege" problem. The Caribbean community were certainly in Britain physically. The "white privilege" concept is an intellectual prerequisite to appreciating The Lonely Londoners. Reni Eddo-Lodge provides a clear conceptualisation:

How can I define white privilege? It's so difficult to define an absence. And white privilege is an absence of the negative consequences of racism ... When I talk about white privilege, I don't mean that white people have it easy, that they've never struggled, or that they've never lived in poverty. But white privilege is the fact that if you're white, your race will almost certainly positively impact your life's trajectory in some way. And you probably won't even notice it (Eddo-Lodge, 2018, pp.86-87).

Discrimination in jobs, housing, education and so forth, based upon the arbitrary fact of skin colour, is the tip of the iceberg. White privilege is "an absence of funny looks directed at you because you're believed to be in the wrong place, an absence of cultural expectations, an absence of violence enacted on your ancestors because of the colour of their skin, an absence of a lifetime of subtle marginalisation and othering - exclusion from the narrative of being human" (Eddo-Lodge, 2018, p. 86). In reality, a person's skin colour is as insignificant as a person's eye colour. Skin colour is an entirely arbitrary marker. There is no scientific basis for 'race' - it is a made up label that has historically legitimised systems of power and wealth production (Kolbert, 2018, pp. 1-34). However, historical power systems (i.e. slavery, segregation, discrimination, ghettoization, etc.) have invested skin colour with grave importance in real experience: "This is the difference between racism and prejudice. There is an unattributed definition of racism that defines it as prejudice plus power" (Eddo-Lodge, 2018, p. 89). EddoLodge explains power through comparison with another example from personal experience:

I found that the only way to keep costs down and still make it to work was to get the train halfway, and cycle for the rest of the journey. An uncomfortable truth dawned on me as I lugged my bike up and down stairs in commuter-town train stations: the majority of public transport I'd been travelling on was not easily accessible. No ramps, no lifts. Nigh-on impossible to access for parents with buggies, or people using wheelchairs, or people with mobility issues, like a frame or a cane. Before I'd had my own wheels to carry, I'd never noticed this problem. I'd been oblivious to the fact that 
this lack of accessibility was affecting hundreds of people. And it was only when the issue became close to me that I began to feel infuriated by it. (Eddo-Lodge, 2018, p. 88)

Eddo-Lodge is describing an imaginative leap of empathy. Her changed life circumstances awakened her to systemic privilege among those without physical handicap on public transport. This Structuralist concept of power de-centres voluntarism (i.e. the tyrant's will) and examines everyday structures in civil society or the lifeworld, or group privileging-exclusion in systems of capital, science, technology, and knowledge, with power conceived sociologically as the consequences of (frequently unconscious) actions. Relatedly, Eddo-Lodge centres "intersectionality" to theorise identity: race, gender, class and handicap (for example) must be recognized as distinct yet intertwined threads if we are to understand systemic inequalities (Eddo-Lodge, 2018, pp. 156-165). She deploys Structuralist theory to explain de-centred identities, and absences manifested as presences in systems of power: "Structural is often the only way to capture what goes unnoticed ... It is not just about personal prejudice, but the collective effects of bias" (Eddo-Lodge, 2018, p. 65). Eddo-Lodge writes:

"I choose to use the word structural rather than institutional because I think it is built into spaces much broader than our more traditional institutions ... Structural racism is dozens, or hundreds, or thousands of people with the same biases joining together to make up one organisation, and acting accordingly ... Structural racism is never a case of innocent and pure, persecuted people of colour versus white people intent on evil and malice. Rather, it is about how Britain's relationship with race infects and distorts equal opportunity" (Eddo-Lodge, 2018, p. 81).

A sociological modernism characterized by Structuralism equally characterizes The Lonely Londoners. In Zola's Germinal (1885), the Montsou coal miners are destroyed by a better-organized state-bourgeois power alliance (i.e. mine owners) in a wilful act of domination to protect the economic system. In The Lonely Londoners, society as a whole remains invisible, as market-driven sectoral divisions of producers and consumers create structural violence (black unemployment, discrimination, exploitation) as a wealth-producing engine. As Olivette Otele has written, "racism is an intergenerational process, transmitted as a legacy of the past" (Otele, 2020, p. 179). It characterises "the economic, political and social legacy of a British society that has historically been 
organised by race", meaning, "in material terms, we are nowhere near equal." (EddoLodge, 2018, pp. 83-84).

Selvon's vision therefore resembles Durkheimian Structuralism, the first Structuralist revolution of the early 20th century, rather than the Marxian class struggle of Germinal. Emphasising "comparison" over the "absolute", Durkheim voiced the core Structuralist principle: beyond networks of relations, no "essential identity" exists (Durkheim, 2009, p. 31). It reappeared in Saussure's 1916 theory of "difference" to explain language (Saussure, 2005, p. 78). No word has intrinsic relation to absolute reality, Saussure taught, against, for example, the Genesis dogma where animals were named in Eden. The changing relations of words to other words give them their existence, with socially ephemeral meanings. Again, Hall's writings on identity lend clarity: "as well as the many points of similarity, there are also critical points of deep and significant difference which constitute 'what we really are'” (Rutherford, 1990, p. 225).

Wills documents such pluralistic identity construction in the Windrush generation:

Many travellers stress the fact that this was the first time they had seen other Caribbean islands, and other islanders. From going ashore to eat snails in Fort-de-France, Martinique ('I nearly vomited when I heard what I had eaten'), to rubbing shoulders with other islanders ... this was a first opportunity for West Indians to take the measure of their region, and its relation to 'the mother country' (Wills, 2017, p. 17).

West Indian identity was formed through migration, as was "black" as an identity. West Indian migrants remarked: "One does not realize that one is coloured until one comes into white society"; "I became black in London, not in Kingston" (Wills, 2017, pp. 20-21). Multiple threads constituted "a new collective consciousness of themselves as Caribbean, and as Black":

The recognition of not being white, and what that meant, would come to shape the experience of these migrant pioneers, and dominate their recollections. It went hand in hand with another realization: that whether you came from Barbados, Trinidad, Jamaica, Antigua or Guyana, there was more connecting you with other islanders than separating you (Wills, 2017, pp. 20-21). 
We thereby demonstrate the priority of Structuralist method for reading The Lonely Londoners as a literature of the Inferno, for Structuralism discloses what is below and hidden. It concerns a plural identity that is never pure or monolithic, except in myth. We simultaneously separate it, as a revolution in language, from either Heideggerian word mysticism or Celinean populism.

\section{The Lonely Londoners as descent into the Inferno}

Robert L. Heilbroner has analysed how underlying "the capitalism of daily life, the system in which men and women participate and by which they are directly affected" is a "netherworld in whose grip the activities of business are caught":

That netherworld may be called the Invisible Hand, or the laws of motion of the system, or the market mechanism ... The structuring effect that this netherworld casts over the course of business activity is never precisely revealed in the pattern of economic events [absence]... but as business activities repeat themselves day after day, the background pattern again becomes evident [presence] ... Consciously or otherwise, their scenarios are also representations of another level of reality - a level of 'nether' pressures expressed through a variety of visible drives and institutions (Heilbroner, 1985, pp. 1618).

The capitalism at the time of The Lonely Londoners centred on Europe's "second Thirty Years War": "the unprecedented death and destruction that occurred after 1914, in what had been, in many respects, Europe's second Thirty Years' War, ended with the defeat of Germany in 1945, heralding a lasting era of peace and prosperity" (Kershaw, 2005, pp. X-XV). After the radical class disparities of $19^{\text {th }}$ century capitalism, convergence occurred between social classes and the birth of a middle class began:

The important reduction in inequality of income which occurred in all rich countries between 1914 and 1945 was foremost the result of the two World Wars and their economic and political shocks (Piketty, 2013, p. 37).

Wider wealth redistribution, combined with accelerated economic growth, means increased goods and services as well as the pluralisation of live modes for more people. Piketty identifies "the definitive collapse of a world with the outbreak of World War I", the interruption of spiralling social inequality which is the core dynamic of 
uninterrupted capitalism (this reasserted itself from the 1980s) (Piketty, 2013, p. 176). Eddo-Lodge provides the global history preceding the crisis/opportunity:

Despite its best efforts to pretend otherwise, Britain is far from a monoculture. Outward-facing when it suited best, history shows us that this country had created a global empire it could draw labour from at ease. But it wasn't ready for the repercussions and responsibilities that came with its colonising of countries and cultures (Eddo-Lodge, p. 15).

The economic conditions prevailing in post-war Britain show how discrimination served to provide an immigrant underclass for a new sector whose remuneration would have been unthinkable for white British workers:

the mechanization of factories in the drive towards greater productivity created new, entirely unskilled labouring jobs. People were needed to heft coal and iron ore around the foundries, to back up men working the modern machines, and the unions fought bitter battles to ensure that immigrant workers were kept out of the better paid grades (Wills, 2017, p. xvii).

It follows that through the system of discrimination black labour was forced into the sub-standard pay grade. The drive to amass capital extracted wealth through creating an exploitative colour-coded labour hierarchy that would persist until "in 1965, Britain's first-ever race-relations legislation was granted by parliament. ... The Race Relations Act stated that overt racial discrimination was no longer legal in public places - although it didn't apply to shops and private housing [it didn't tackle endemic housing discrimination]" (Eddo-Lodge, 2018, pp. 26-27). This immigrant underclass partly explains how Britain's “economy quite quickly recovered and set in train the industrial boom of the 1950s" (Wills, 2017, p. xvii):

Rural immigrants, so often described as 'pre-modern' or savage outliers to industrial society, not only lived in the negative underside of the new suburban affluence, they also powered it - building the roads, cars and goods which made English suburban lives possible (Wills, 2017, p. xx).

This sketches the historical and sociological context for Selvon's Inferno as an experience of capitalism, a tour of a "twilight subterranean enclave" (Nasta, 2018, p. 3). The Lonely Londoners opens with a "grim winter evening", invoking "a kind of 
unrealness about London, with fog sleeping restlessly over the city and the lights showing in the blur as if is not London at all but some strange place on another planet..." (Selvon, p. 1). This references the "Unreal City" in the opening section of T.S. Eliot's The Wasteland (1922), entitled The Burial of the Dead ("Under the brown fog of a winter dawn, A crowd flowed over London Bridge, so many, I had not thought death had undone so many") (Eliot, 2016, p. 7). Selvon's central character, Moses, echoes the Book of Exodus. The Prophet Moses was born when the Israelites were an enslaved minority, increasing in population under the Egyptian Pharaoh. Just as Moses led the Israelite Exodus from Egypt across the Red Sea, Selvon's Moses guides Caribbean migrants across London. Like Eliot's Wasteland, Moses' experiences mix prophecy and satire through "episodic plot structure" and multiple "little worlds" (Habila, 2007, p. 3). Moses helps reluctantly, because of the ubiquitous loneliness of the immigrant experience:

That was the hurtful part of it - it is not as if this fellar is his brother or cousin or even friend; he don't know this man from Adam ... Because it look to Moses that he hardly have time to settle in the old Brit'n before all sorts of fellars coming straight to his room in the Water when they land up in London from the West Indies, saying that so and so tell them that Moses is a good fellar to contact, that he would help them get place to stay and work to do. ... He don't know how he always getting in a position like this, helping people out (Selvon, 2006, pp. 1-4).

Moses is a hero because help is the anti-thesis of isolation, the seed of solidarity. Selvon's Inferno is not Dante's eternal punishments below the earth, but the world of "hustle" (the economic oppression, discrimination, low pay, and exploitation of systemic racism), public "spaces" (buses, unemployment, tax, and immigration offices), and the atomised communities occupying Notting Hill and the Harrow Road (Nasta, 2018, p. 3). Moses leads them not to an otherworldly heaven, but to find a job and a settled life. The Inferno is the market mechanism. Individual isolation results from economic commodification and the resulting mistrust poisoning social relations: "When it come to making money, it ain't have nothing like 'ease me up' or 'both of we is countrymen together' in the old London ... every man on his own" (Selvon, 206, pp. 6,17). This absence of conviviality produces strong feelings of nostalgia for 'home':

This is a lonely miserable city, if it was that we didn't get together now and then to talk about things back home, we would suffer like hell. Here is not like home where you have 
friends all about ... you want to go to somebody house and eat a meal, you want to go on excursion to the sea, you want to go and play football and cricket. Nobody in London does really accept you. They tolerate you, yes, but you can't go in their house and eat or sit down and talk (Selvon, 2006, p. 126).

The problem is, "It ain't have no prospects back home, boy" (Selvon, 2006, p. 125). This reflects colonial policy, with "decades of under-investment in agriculture and little or no investment in anything else. In 1946 a survey of 11 Jamaican towns, 30,000 men and women were actively looking for jobs and could not find them - nearly 16 per cent of those over the age of 14" (Wills, 2017, p. 11). Atomisation is the core experience of Selvon's Inferno, extended to all Londoners in the modern age:

It have people living in London who don't know what happening in the room next to them, far more the street, or how other people living ... It divide up into little worlds, and you stay in the world you belong to and you don't know anything about what happening in the other ones except what you read in the papers (p.60).

This lack of solidarity through public communication prevents self-organisation among London's diverse populations, thwarting greater democratisation and new multi-cultural identities. Non-communication results in an economic system taking unfair advantage to maximise surplus extraction. Moses envisions new solidarities: "It have a kind of communal feeling with the Working Class and the spades, because when you poor things does level out, it don't have much up and down" (Selvon, 2006, p. 61).

Moses leads multiple characters through the 1950s industrial boom, where cheap manpower was needed, and the lowest economic strata was reserved for Caribbean migrants:

Then Tolroy take Lewis to the factory and get a work for him. It wasn't so hard to do that, for the work is a hard work and mostly is spades they have working in the factory, paying lower wages than they would pay to white fellars (Selvon, 2006, p. 52)

One character, Cap, recognizes hell in this industrial landscape:

The people who living in London don't really know how behind them railway station does be so desolate and discouraging. It is like another world. All Cap seeing is railway line and big junk of iron all about the yard, and some thick, heavy cable lying around. It 
have some snow on the ground, and the old fog at home as usual. It look like hell, and Cap back away when he see it (Selvon, 2006, p. 35).

The economic system maintains a development level sufficient to meet the food, clothing, medical care, and housing of all, but systematically excludes an imaginatively constructed group from the goods of political or social freedom. Passages such as, "they want you to live up to the films and stories they hear about black people living primitive in the jungles of the world", are not harmless stereotypes born of ignorance but the imaginative elements of material exclusion in politics and economy (Selvon, 2006, p. 100). Historical evidence reveals such imaginative systemicity in contemporary police reports:

the records of police constabularies investigating 'coloured' crime, reports of interracial tension inside government hostels, statements by police and the judiciary on the Notting Hill riots, parliamentary debates on immigration and race relations legislation, ethnographic and sociological surveys of attitudes to race in relation to the housing crisis, and employment. ... these documents are saturated with stereotypes of migrants, both ethnic and racial ... These records offer plenty of insight into and information about attitudes towards the newcomers. They are eloquent when it comes to blind spots (Wills, 2017, p. xx).

Moses, confronted with Piccadilly Circus, sees the likeness of Dante's ninth circle or the centre of hell ("we passed through the centre, so everything was reversed") (Dante, 2018, p. 233):

that circus represent life, that circus is the beginning and the ending of the world. Every time he go there, he have the same feeling like when he see it the first night, drink cocacola, any time is guinness time, bovril and the fireworks, a million flashing lights, gay laughter, the wide doors of theatres, the huge posters, everready batteries, rich people going into tall hotels... (p. 79)

The Inferno is no mere regime of parasitic exploitation, but also an imaginative realm shared by every character. Marshall McLuhan argues that proliferating technologies have created whole new environments: "it is sometimes a bit of a shock to be reminded that, in operational and practical fact, the medium is the message. This is merely to say that the personal and social consequences of any medium - that is, of any extension of ourselves - result from the new scale that is introduced into our affairs by 
each extension of ourselves, or by any new technology" (McLuhen, 1964, p. 23). The opium of the masses has become limitless consumer desire in an economy ceaselessly inventing new commodities. Dante dreamed of worldwide integration, but the inclusive consciousness of universal consumerism is the empty heart of Selvon's Inferno. Selvon's Inferno is built upon the disjuncture between idealised expectations among Caribbean migrants concerning Britain as the 'mother country' (i.e. the advertising), and the harsh reality of migrant life in Britain (i.e. the labour market and human commodification):

Is like when you back home and you hear fellars talk about Times Square and Fifth Avenue, and Charing Cross and gay Paree. You say to yourself, 'Lord, them places must be sharp.' Then you get a chance and you see them for yourself, and is like nothing (Selvon, 2006, p. 73).

The disillusionment results from "West Indian immigrants [having] been brought up to believe they were guaranteed a welcome in the 'mother country' ... migrating was simply making good on a promise that had long been made to them as citizens of the Empire" (Wills, 2017, p. 3). Far from mere disillusionment, or innocence lost, it is an existential crisis inflicted by systemic racism. Selvon documents pathology. The arbitrary feature of skin colour is transformed into a demon with an independent life:

...as soon as the landlady see you she say the room let already ... Keep the Water White.... And Galahad watch the colour of his hand, and talk to it, saying, 'Colour, is you that is causing all this, you know. Why the hell you can't be blue, or red or green, if you can't be white? You know is you that cause a lot of misery in the world. Is not me, you know, is you! I ain't do anything to infuriate the people and them, is you! Look at you, you so black and innocent, and this time so you causing misery all over the world!' So Galahad talking to the colour Black, as if is a person. (p. 77)

The Lonely Londoners portrays the psychological disturbances inflicted by racism, showing the arbitrary character of social identity markers based on skin colour in different societies:

Bart have light skin. That is to say, he neither here nor there, though he more here than there. When he first hit Britain, like a lot of other brown skin fellars who frighten for the lash, he go around telling everybody that he is Latin American... . Bart had ambition that always too big for him (Selvon, 2006, p. 46). 
Identity emerges from conditioned genesis, or political and economic orders constructed in culture: "whiteness in Britain was not a social category - defining a hierarchy of class and power, as it did in Jamaica, Trinidad, and Barbados [i.e. shades of blackness] - but a political one, defining those who belonged and those who did not" (Wills, 2017, pp. 20-21). Londoners are "lonely" as human commodities under the pressures of the market mechanism Selvon's Inferno:

When Bart leave the hostel he get a clerical job and he hold on to it like if is gold, for he frighten if he have to go and work in a factory - that is not for him at all. Many nights he think about how so many West Indians coming, and it give him more fear than it give the Englishman, for Bart frighten if they make things hard in Brit'n. If a fellar too black, Bart not companying him much, and he don't like to be found in the company of the boys, he always have an embarrass air when he with them in public... (Selvon, 2006, pp. 47-48).

Images of the Dantean Inferno recur throughout The Lonely Londoners. Dante's deceased lover Beatrice, who sends Virgil to guide him to Heaven (Dante, 2018, pp. 1617), is recurrently sought by the character Bart:

Eventually the girl move from where she was living and Bart can't find her at all. He start to get frantic. He look all about, any time he see any of the boys: 'You see Beatrice anywhere?' (p. 51)

This recurrent image suggests the loss of a path to Heaven. As in Dante's Inferno"I was among those who are in limbo" (Dante, 2018, p. 15) - the characters in The Lonely Londoners are marooned in inescapable limbo:

Harris looking at his watch anxiously and saying that he has an important engagement, but all the same never getting up to go, and Bart saying that he sure one of the boys must have seen his girl Beatrice ... How many Sunday mornings gone like that? ... how to stop all this crap, how to put a spoke in the wheel, to make things different. Like how he tell Cap to get to hell out one night, so he should do one Sunday morning when he can't bear it anymore: Get to hell out, why the arse you telling me about how they call you a darkie, you think I am interested? (Selvon, 2006, pp. 136-137)

Just as the River Styx makes up the swampy waters of the fifth circle of Hell, where Dante witnesses people "naked and with a look of anger on their faces, they hit each other, not just with their hands, [but] tearing each other apart with their teeth" (p. 57), Moses sees violent combat in the Thames: 
The old Moses, standing on the banks of the Thames. Sometimes he think he see some sort of profound realisation in his life, as if all that happen to him was experience that make him a better man, as if now he could draw apart from any hustling and just sit down and watch other people fight to live. Under the kiff-kiff laughter, behind the ballad and the episode, the what-happening, the summer-is-hearts, he could see a great aimlessness, a great restless, swaying movement that leaving you standing in the same spot. As if a forlorn shadow of doom fall on all the spades in the country (Selvon, 2006, p. 139).

Selvon's novel exposes the troubled post-war birth of Britain as the vibrantly multi-cultural but conflicted society it has become today, still ensnared in colonial legacies. The Lonely Londoners depicts blackness as an artificially monolithic projection and diverse identities among black Londoners:

in the lounge they would sit around - the genuine fellars with text-books in hand, and some fellars with the Worker, and big discussion on politics and thing would start up. Especially them who come from British Guiana and don't want federation in the West Indies, saying that they belong to the continent of South America and don't want to belittle themselves with the small islands. Meanwhile a African fellar would be playing the piano - he would give you a classic by Chopin, then a calypso, then one of them funny African tune (Selvon, 2006, p. 30).

Habila rightly underlines Selvon's humanist "message": "although we live in societies increasingly divided along racial, ideological and religious lines, we must remember what we still have in common - our humanity" (Habila, 2007, p. 3). Habila cites this passage: "Everybody living to dead, no matter what they doing while they living, in the end everybody dead" (Selvon, 2006, p. 52). We better understand, now, how Selvon's humanist purpose differed from Foucault's anti-universalist celebration of cultural fragments. Yet Moses' reference to universal belonging in death is also suggestive of the Inferno, as in the Dantean words repeated by Eliot ("I had not thought death had undone so many") (Dante, 2018, p. 23).

Selvon forged his own literary narrative strategy that rejected linear continuity in favour of non-linear encounters between Moses, a Dantesque Pilgrim and Guide, and an underworld of characters. London is the Inferno, its encounters producing a cumulative impression of life's opportunities repeatedly hindered by racial injustice: 
You work things out in your own mind to a kind of pattern, in a sort of sequence, and one day bam! something happen to throw everything out of gear, what you expect to happen never happen, what you don't expect to happen always happen, and you have to start thinking all over again (Selvon, 2006, p. 40).

Britain is a contemporary ancient Rome and moral wasteland. We can make a case for Selvon initiating a genre in the post-war British literature of multi-culturalism.

\section{Colin MacInnes' Absolute Beginners as successor to The Lonely Londoners}

Selvon's creative richness is revealed when juxtaposed with Colin MacInnes Absolute Beginners, which similarly featured "a shadow group of people thrust into the daylight" in focusing on London's West Indian communities (Habila, p. 2). MacInnes focused on the 1958 Notting Hill riots and the rise of fascist violence, but above all the complicity of ordinary white Londoners in racism:

That milk that arrives mysteriously every morning, I suppose it brings us life, but if trouble comes, it's been put there - or the bottles it comes in have done - by the devil ... And about those who watched, I saw something new to me ... they didn't even seem to enjoy themselves particularly - I mean, seeing all this - they didn't shout, or bawl, or cheer; they just stood by, out of harm's way, these English people did, and watched. Just like at home at evening, with their Ovaltine and slippers, at the telly (MacInnes, 2011, p. 246).

MacInnes deeply explores London dialects. His central character, like Moses, simply wanders the city without any specific plot device, encountering denizens of the Inferno whose personas reveal facets of new multi-cultural London. The central character, white but immersed in African American and West Indian youth culture, must decide to remain apathetic or risk confronting racist violence - thereby exposing himself to fascist violence. The sight of an elderly white shopkeeper giving refuge to West Indians in her grocery breaks his initial indecision:

This one old girl, with her grey hair all in a mess, and her old face flushed with fury, she stood there surrounded by this crowd of hundreds, and she bawled them out. She said they were a stack of cowards and gutter bastards, the whole lot of them... (MacInnes, 2011, pp. 244-248) 
MacInnes Absolute Beginners thereby culminates in a call for multi-cultural solidarity as a new British identity. It also deals with the construction of identity through commodification, especially regarding the "teenager" as the creation of postwar economic boom and the music industry: ''They buy us younger every year,' I cried. 'Why, Little Mr L.'s voice hasn't even dropped yet, so who will those taxpayers try to kidnap next?'” MacInnes, 2011, p. 9) Teenaged identity is no natural fact but the cultural construction of a political-economic order: "he's one of the last of the generations that grew up before teenagers existed", the main character says of his estranged older brother (MacInnes, 2011, p. 48). His brother lectures him: “your trouble is, you have no social conscience ... Who put you where you are ... It was the Atlee Administrations ... You're a traitor to the working-class!" (MacInnes, 2011, p. 48) This portends his political awakening. Teenagers harvest personal wealth through the new underground economy of illegal drugs and commodified sex (i.e. pimping and pornography), as their parents in the 1930s never could, but enjoy no political rights or responsibilities. The main character's father explains:

You've got no idea what that pre-war period was like. Poverty, unemployment, fascism and disaster and, worst of all, no chance, no opportunity, no sunlight at the end of the corridor, just a lot of hard, frightened, rich old men sitting on top of a pile of dustbin lids to keep the muck from spilling over." (MacInnes, 2011, p. 44)

Meanwhile, the main character retorts to his mother:

'Who made us minors? ... You made us minors with your parliamentary what sits ... You thought, 'That'll keep the little bastards in their places, no legal rights, and so on', and you made us minors. Righty-o. That also freed us from responsibility, didn't it? Because how can you be responsible if you haven't any rights? And then came the gay-time boom and all the spending money, and suddenly you oldos found that though we minors had no rights, we'd got the money power (MacInnes, 2011, p. 51).

Teenagers are the target of contempt and discrimination: "[The banker] gave me the [bank] notes as if they were two deformed specimens the bank happened to have it was ashamed of, then nipped round his counter and saw me out of the door, and locked it swiftly on my heels" (MacInnes, 2011, p. 35). Throughout most of the novel, the unnamed central character remains convinced that political apathy is fundamental to teenaged identity: 
'Young peoples in the Soviet Union and the USA,' I told him, clearly and very slowly, 'don't give a single lump of cat's shit for the bomb ... You don't have to travel to know what it's like to be young, any time, anywhere (MacInnes, 2011, pp.30-31).

Youth is a universal commodity. As in The Lonely Londoners, post-war Britain is depicted as being lost in the new post-Empire Cold War environment: "her position is that she hasn't found her position" (MacInnes, 2011, p. 32). The main character, although white and comparatively privileged, is equally as isolated as the characters in The Lonely Londoners. His early life is a search for belonging in multiple places: "for the first time, here was a family: at any rate, a lot, a mob, a click I could belong to." (p. 82) He finds his most important belonging in the "jazz clubs", the "third item in my education" (p. 83). He treats Billie Holiday as a holy icon: "Lady Day has suffered so much in her life that she carries it all for you, and soon I was quite a cheerful cat again" (p. 32). Culturally, he cannot differentiate his identity in terms of belonging as either white or black, even as he enjoys white privilege. In a revealing moment, he (unsuccessfully) consoles one of his best friends - a black youth with a white half brother - when fascist agitators threaten a race riot:

you're one of us, big boy, I mean home-grown, as much a native London kid as any of the millions, and much more than hundreds of pure pink numbers from Ireland and abroad who've latched onto the Welfare thing, but don't belong here like you do' (MacInnes, 2011, p. 74).

The suffering of racially mixed families similarly figures in The Lonely Londoners: Look at Joseph. He married to a English girl and they have four children, and they living in two rooms in Paddington. He apply to the LCC for a flat, but it look like he would never get one. Now the children big enough to go to school, and what you think? Is big fight every day because the other children calling them darkie. (Selvon, 2006, p. 126)

The main character in Absolute Beginners perceives racism as socially learned, not a natural. Small children do not display it until taught by adults: "I noticed, not for the first time, how, in the underground movement of the juveniles, they hadn't been educated up yet to the colour thing. Fists and wits, they were all that mattered, and the only enemy was teacher" (MacInnes, 2011, p. 80). MacInnes used Selvon's template of London as the Inferno, the plot replaced by non-linear encounters, a central character 
that is Dantesque Pilgrim and Guide, wandering among an underworld revealing the new meanings of post-war multi-cultural London (Habila, 2007, p. 2). MacInnes' novel culminates by voicing salvation from the Inferno in a multi-cultural solidarity that creates a new and more democratic British identity.

Where Habila writes, “there isn't really an ending; instead of a definite closure [in The Lonely Londoners], the reader is left with a sense of vague and gloomy continuum", in fact, Selvon's novel does close with a glimpse of redemption. Public writing is an act of self-representation through a counter-narrative subverting systemic racism (Habila, 2007, p. 1):

Daniel was telling him how over in France all kinds of fellars writing books what turning out to be best-sellers. Taxi-driver, porter, road-sweeper - it didn't matter. One day you sweating in the factory and the next day all the newspapers have your name and photo, saying how you are a new literary giant (Selvon, 2006, p. 139).

The African-American writer James Baldwin, publishing from Paris, is the implied hero. By publicly telling their own stories, the London West Indian might overcome the erasing effects of racist narratives in media and police reports to exist and belong in British society as social equals. MacInnes and Selvon conclude with calls to different types of activism.

If Selvon's work germinates the Inferno thematic, it had its precursor in Jean Rhys' Voyage in the Dark. It contains the core elements of the Inferno: identity as atomisation/commodification, absence and nostalgia, and the frustrated aspiration to public solidarity through communicative multi-culturalism. It is preoccupied with West Indian migrant experience in Britain, focusing on gender and whiteness. Rhys dizzyingly mixes French, Creole and cockney English dialects. The Inferno is an anti-narrative device for tracing the order-bestowing influences of capitalism as an unseen force in everyday life, with myriad effects for diverse human experiences.

\section{Jean Rhys' Voyage in the Dark as the 1930s antecedent}

Superficially, the novel recounts nineteen-year-old Anna Morgan's aimless everyday ramble through a passage in her life as a white Caribbean immigrant trying to 
survive in bleak and grey 1930s London. Like the opening passage of The Lonely Londoners, Anna experiences London as an infernal dream:

It was as if a curtain had fallen, hiding everything I had ever known. It was almost like being born again. The colours were different, the smells different, the feelings things gave you right down inside yourself was different. Not just the difference between heat, cold; light, darkness; purple, grey. But a difference in the way I was frightened and the way I was happy (Rhys, 2000, p. 3).

We are in a city of the dead. Anna tells us "parts of London are as empty as if they were dead" (Rhys, 2000, p. 32). The opening segment alludes obliquely to sex workers ("chorus girls") on the streets at night, weaved into the remembered threads of Anna's Caribbean family history:

I didn't like England at first. I couldn't get used to the cold. Sometimes I would shut my eyes and pretend that the heat of the fire, or the bed-clothes drawn up around me, was sun-heat; or I would pretend I was standing outside the house at home, looking down Market Street to the Bay ...Sometimes it was as if I were back there and as if England were a dream. At other times England was the real thing and out there was the dream, but I could never fit them together (Rhys, 2000, p. 3-4).

Anna's dualism suggests heaven and earth, reality and ephemerality. Recurrent images of redness and fire suggest that Anna is in the Inferno, feeling "too much like a ghost" (Rhys, 2000, p. 94):

There was a red-shaded lamp on the table, and heavy pink silk curtains over the windows. There was a hard, straight-backed sofa, and two chairs with curved legs against the wall - all upholstered in red. The Hoffner Hotel and Restaurant, the place was called ... There were red carnations on the table and the fire leaping up. ... There was fire but the room was cold. I walked up to the looking-glass and put the lights on over it and stared at myself. It was as if I were looking at somebody else (Rhys, 2000, p. 14-17).

Anna's environment is peopled by demonic hybrids of human and animal: "Just like a rabbit, she was, like a blind rabbit. There was something horrible about that sort of praying. I thought, 'I believe there's something horrible about that sort of praying'” (Rhys, 2000, p. 15). Another has "black hair and little red eyes", while another has "eyes [with] a blind look, like a dog's when it sniffs something" (Rhys, 2000, pp. 19, 38). Anna 
recurrently describes the fire as cold, destructive but incapable of providing refuge: "I lay there for a long time, listening. The fire was like a painted fire; no warmth came from it" (Rhys, 2000, p. 17). Fire suggests a second level of eternal reality, like a Platonic form: "The things spread out on the dressing-table shone in the light of the fire, and I thought, 'When I shut my eyes I'll be able to see this room all my life'” (Rhys, 2000, p. 29).

Voyage in the Dark is structured around the pregnancy, presaging an ending of birth and death, three sections dividing the novel into trimesters that resemble pregnancy and childbirth. We witness Anna's descent, moved from her Caribbean home to England by a callous stepmother, following her father's death. The stepmother cheats Anna of her inheritance from a Caribbean Estate/ex-slave Plantation, forcing her to support herself. As a "chorus girl", understood by most in the narrative as meaning prostitution, Anna is treated as "other" by the white English women in the profession:

'She's always cold,' Maudie said. 'She can't help it. She was born in a hot place. She was born in the West Indies, or somewhere, weren't you kid? The girls call her the Hottentot. Isn't it a shame? (Rhys, 2000, p. 8)

"Hottentot" is a racist epithet for a black person. Elsewhere, Anna 'passes' as English because of her white skin, and is unknowingly insulted by interlocutors who assume she must share their hatred of foreign immigrants:

'Men are devils, aren't they? But of course I don't really care a damn about them. Why should I? I can earn my own living. I'm a masseuse - a Swedish masseuse. And, mind you, when I say I'm a masseuse I don't mean like some of those dirty foreigners. Don't you hate foreigners?' 'Well,' I said, 'I don't think I do; but, you see, I don't know many.' 'What?' Ethel said, looking surprised and suspicious, 'you don't hate them?' (Rhys, 2000, p. 91)

In these situations, Anna plays along, showing her white privilege by concealing her foreign origins - of which she is in reality very proud ("I'm a real West Indian ... I'm the fifth generation on my mother's side", she boasts when drunk) (Rhys, 2000, p. 43). Anna thereby evades trouble (i.e. job/accommodation discrimination), but makes obliquely revealing comments when angered. When her boss, Ethel, shouts "Why don't you clear out?" Anna replies, “I can't swim well enough, that's one reason” (Rhys, 2000, p. 120). Ethel fails to see the implication. 
Behind appearances, Anna's identity is complex. She repeatedly talks of wanting to be black. On one level, being from a black majority country, Anna may share the feeling of one black Windrush arrival: "I had hardly even seen more than twelve white people together before. I had always been a member of the majority race." (Wills, 2017, p.18). However, the reason seems more intimate. During her upbringing, black people treated Anna kindly and white people harshly in her extended family:

I wanted to be black. I always wanted to be black. I was happy because Francine was there, and I watched her hand waving the fan backwards and forwards and the beads of sweat that rolled from underneath her handkerchief. Being black is warm and gay, being white is cold and sad (Rhys, 2000, p. 24)

We understand that, given the political and economic order, women are unable to work and meet the basic cost of living. They are kept poor and hence unequal through a gendered economy. Young women are therefore preyed upon, the targets of much older men who recognize and exploit their plight as if they were commodities in a market ("Vincent said, 'Well, how's the child? How's my infantile Anna?'”) (Rhys, 2000, p. 64). Another tells her, 'I'm too old for this sort of thing,' he said; 'it's bad for the heart'”. We hear Anna's private reflections: “... His face was white ... A pretty useful mask that white one watch it and the slobbering tongue of an idiot will stick out..." (p. 152). The predatory trap is exemplified in a conversation between Anna and a companion:

D'you know what a man said to me the other day? It's funny, he said, have you ever thought that a girl's clothes cost more than the girl inside them? ... I had to laugh, because after all it's true isn't it? People are much cheaper than things. And look here! Some dogs are more expensive than people, aren't they? (Rhys, 2000, p. 36)

Like The Lonely Londoners, individuals (women this time, as are teenagers in MacInnes) are commodified and thereby atomised in a comparable Inferno of solitude. Meanwhile, social pressures masking economic forces compel women to desire status commodities (in a return to Selvon's central circle of hell):

About clothes, it's awful. Everything makes you want pretty clothes like hell. ... The ones without any money, the ones with beastly lives. Perhaps I'm going to be one of the ones with beastly lives. They swarm like woodlice when you push a stick into a woodlice nest at home. And their faces are the colour of woodlice. (Rhys, 2000, pp. 18-19) 
Anna becomes involved with an older man who supports her financially (i.e. she was to be evicted from her rented room, "I don't want no tarts in my house, so now you know"), then abandons her when she shows resistance to being mocked and humiliated by his arrogant entourage (Rhys, 2000, p. 22). Anna then begins a downward spiral into alcoholism, mental illness and prostitution. This culminates in a botched illegal abortion, which the older man coldly pays for through an intermediary in an act affirming superior social status much as one might feed a stray animal.

Voyage in the Dark examines attitudes towards wealth and how society prioritises money and the accumulation of possessions. The experience of being with or without money has a psychosomatic affect upon Anna's bodily wellbeing:

I opened the letter and there were five five-pound notes inside ... I took the money from under my pillow and put it into my handbag. I was accustomed to it already. It was as if I had always had it. Money ought to be everybody's. It ought to be like water. You can tell that because you get accustomed to it so quickly. ... All the time I was dressing I was thinking what clothes I would buy. I didn't think about anything else at all, and I forgot about feeling ill. ... 'Will you light the fire in my room, please?' I said. My voice sounded round and full instead of small and thin. 'That's because of the money,' I thought. (Rhys, 2000, pp. 19-20)

The Inferno is economics. Just as money is important because it liberates individuals, poverty traps them and constrains their potential. We see that money is the transformative alchemy in Anna's Inferno: “The streets looked different that day, just as a reflection in the looking-glass is different from the real thing ... Then I had seven pounds left. I began to feel ill again. When I breathed my side hurt. I got a taxi and went back to Judd Street. The fire wasn't laid" (Rhys, 2000, pp. 21-22). The novel investigates conventions shaping wealth and possessions, the boundaries between yours, and mine, and failures to divide wealth equitably within nations and across borders. It suggests how economic inequality undermines the positive value in human relationships and intrinsically produces systemic power abuse.

Rhys sets up Voyage in the Dark against Joseph Conrad's Heart of Darkness (1899), suggesting the journey to the predatory capitalism of 1930s England is a sojourn into darkness, monotony and despair. Anna's birthplace, Dominica in the West 
Indies, is presented through recurrent haunting memories of vivid light and bright colour, a mango tree invoking a lost Garden of Eden: "The mango tree was so big that all the garden was in its shadow and the ground under it always looked dark and damp" (Rhys, 2000, p. 33). She tells us: "The sun at home can be terrible, like God. This thing here - I can't believe it's the same sun..." (p. 59). Meanwhile, religious fanatics in the streets shout at Anna: "'Laugh! Your sins will find you out. Already the fear of death and hell is in your hearts, already the fear of God is like a fire in your hearts'” (p. 38). Yet Anna's nostalgia for Dominica and desired identity with blackness is shot through with recollections of the violent subjugation that made her family Estate possible in the history of black chattel slavery:

I saw an old slave-list at Constance once ... it was hand-written on that paper that rolls up. Parchment, d'you call it? It was in columns - the names and the ages and what they did and then General Remarks ... The sins of the fathers Hester said are visited upon the children unto the third and fourth generation ... Children, every day one should put aside a quarter of an hour for meditation on the Four Last Things ... The Last Four Things are Death, Judgment, Hell and Heaven (Rhys, 2000, pp. 41-44).

Elsewhere, Anna's consciousness is pierced by other atrocities of Dominican history in a floating mock documentary voice:

The Caribbean Sea. 'The Caribs indigenous to this island were a warlike tribe and their resistance to white domination, though spasmodic, was fierce. As lately as the beginning of the nineteenth century they raided one of the neighbouring islands, under British rule, overpowered the garrison and kidnapped the governor, his wife and three children. They are now practically exterminated (Rhys, 2000, p. 87).

By the end of the novel, Anna's mental illness shows her idealised memories of Dominica collapsing into contemporary images of London. The Platonic dualism is unsustainable because everything Anna despises about London's coercive capitalism in fact underpinned her childhood paradise in Dominica:

Somebody said in my ear. 'That's your island that you talk such a lot about' ... the ship was sailing very close to an island, which was home except that the trees were all wrong. These were English trees, their leaves trailing in the water... (Rhys, 2000, p. 136). 
Anna presents the tension between integration into English society and assertion of a Caribbean cultural identity, distorted by the violent history of colonial power and "Loathsome London, vile and stinking hole..." (Rhys, 2000, p. 37). Anna's alienated and subordinated identity is complicated her gender and her whiteness, in a non-linear portrait of the complexities of intersectionality. Each fragment of Anna's disintegrating consciousness suggests other worlds outside its frame, merged with images of nature, deprivation and desperation, religious commentary, like a scrapbook of remembrances. It is a chronicle of birth and life where the economic and political conditions of Anna's existence make bringing her fatherless child into the world a cruel impossibility. As Anna says, encapsulating the novel:

as soon as a thing has happened it isn't fantastic any longer, it's inevitable. The inevitable is what you're doing or have done. The fantastic is simply what you didn't do. That goes for everybody (Rhys, 2000, p.136).

After falling dangerously ill following her botched illegal abortion, Anna is confronted by a doctor who speaks of her as if she were a machine - much like the men who have preyed upon her throughout the novel:

You girls are too naïve to live, aren't you? ... 'Oh, so you had a fall, did you?' the doctor said. His hands looked enormous in rubber gloves. He began to ask questions. ... He moved around the room briskly, like a machine that was working smoothly ... 'She'll be all right,' he said. 'Ready to start all over again in no time, I've no doubt' (Rhys, 2000, pp. 154-155).

The sex machine has broken down, but it can be easily repaired, the doctor implies as Anna's descends into London's 1930s Inferno. Anna will soon be forced back into prostitution through economic pressures produced by political policies of gender discrimination. She is indeed wandering the circles of hell, and the impossibility of a future in family, belonging and subsequent generations is conveyed in her reflections upon her baby: "all the time thinking round and round in a circle that it is there inside me, and about all the things I had taken so that if I had it, it would be a monster" (Rhys, 2000, p. 139). 


\section{Conclusion}

We are encountering the Inferno of Marlowe, not Dante, in these three works. Mephistopheles gave Doctor Faustus the kingdom of infernal rule. Christopher Marlowe allegorised early modern power. Dante's Inferno had been a machine, immaculate, an "eternal place" working to perfection. In God's wrath, punishment and crime conjoined. Dante was a spectator, never an agent, in his underworld descent. The scientific linking of disease to cause and effect, rather than divine punishment, was recent in Dante's Italy with the physician Taddeo Alderoti. The weight of sin grounded nine descending circles of suffering. Prohibitions against promiscuity, homosexuality, etc. exemplified Heidegger's "cultural paradigm" - community rules for salvation and damnation. In Marlowe's secular machine, the moral issues of the wheel-lock-musket (i.e. Bartholomew's Day massacre, the African slave trade) were more serious than sex or the "violence against nature" of the seventh circle. Marlowe confronts the early modern Circle of Violence and Progress: capital, science, technology, and knowledge, with power conceived as the consequences of actions. A terrible agency zoomed violently upwards and heavily fell, depicting hazardous change. Faust was promised control over everything. He ended up a pile of "limbs" all "torn asunder by the hand of death" (Marlowe, 1998, p. 75).

These three novels teach us that monolithic identity is a myth, not a reality. No white American, as James Baldwin said, can be certain he has no black ancestry (Ove, 1969). The same holds for every American black. This is the legacy of the slave system, where white masters routinely raped African American women, long before Americans of all colours married freely under the law. It also reflects the findings of modern science, where modern humans very likely all share black African ancestors. Pure race is meaningless except as a fascist fiction, yet it continues to pervade a corrupted 'common sense'. Wills complicates Windrush identity and the post-war British multi-cultural society:

What has been called 'the Windrush generation' was comprised not only of people from the Caribbean, but also Poles, Latvians, Lithuanians, Ukrainians, Italians, Maltese, Cypriots, Indians and Pakistanis, plus the largest immigrant group, the Irish...[These arrivals] were to form the vanguard of multi-culturalism [including] forced labourers, 
victims of concentration camps, former prisoners of war, the millions displaced by the redrawing of boundaries in Eastern Europe - by the end of the war there were 7 million displaced people in Germany alone... (Wills, 2017, p. xii)

Wills nevertheless sees a common experience: "Immigrants from Europe and the Commonwealth differed in all sorts of ways but what they shared was the experience of belonging securely neither to the places they had left nor to the places they had chosen to make their home. It was ... a third space - the limbo of migrant culture." (Wills, 2017, p. xi). This is the limbo of Selvon's Inferno.

Habila rejects critics who have described The Lonely Londoners as a collection of mini-biographies. He writes: "what makes this collection stand out is how painstakingly the author has drawn them; Selvon has a way of investing the most tiny, insignificant detail with a universe of meaning" (Habila, p. 2). It is only through the close examination of details that we understand meanings in the lifeworld. Selvon's novel examines multiple individuals caught in a public world, a civil society defined by systemic racism. This was not Britain's destiny but a conjunctural political creation. As Wills has argued, the "arrival and growth [of migrant communities] gave British society an opportunity of recognising its own blind spots, and also looking beyond its own nose to a widening horizon of human integrity" (Wills, 2017, p. ix). Post-war migrants "provided an opportunity for reflection. Through the eyes of strangers Britons could look at themselves ... It was a test of the values and organization of British society, and society in large part - failed the test" (Wills, 2017, p. xviii). Wills refers to what Eddo-Lodge calls "absence" as a missed historical opportunity for becoming a "vibrant multi-cultural democracy":

forgo the reassuring structures of standard national, public narratives and even the established chronology in which the past leads into the present and eventually the future ... a kaleidoscope of the fragmentary experiences of metropolitan migrant life ... intersected and began to converge with the main current of British politics and society, and change it in its turn (Wills, 2017, p. xii).

This was Gandhi's central message. Colonialism did not merely transform India, but Britain equally. The historian Olivette Otele has shown how national icons of French 
and Russian culture are incomprehensible without the influence of their black family members and lovers, who official histories have erased from existence:

Jeanne Duval was the poet Baudelaire's muse and lover, a black model and sex worker. Baudelaire would not have been the poet he was without Jeanne, as she influenced him deeply ... [yet] because of his tumultuous relationship with Jeanne, he failed to represent, in his contemporaries' view, the essence of whiteness and Frenchness ... because Baudelaire's defenders could not find a way to incorporate Duval and other black women into the definition of Frenchness, they demonised her and expunged her from the record as much as possible (Otele, 2020, p. 101).

Regarding Pushkin, Otele writes:

Gannibal's great-grandson, Pushkin, never shied away from his family's African heritage. In the first edition of his novel in verse Eugene Onegin (1825), he warns his readers that he plans to write a biography of his black ancestor (Otele, 2020, p. 170).

Otele therefore poses the "question of migration ... the vastly diverse interactions that took place between the colonisers and the local populations" (Otele, 2020, p. 130). This article has addressed this "mutual influence between colonised and coloniser as far as literary production is concerned", in the creation of contemporary multi-cultural Britain and Europe in general (Otele, 2020, p. 132).

Regarding Structuralism, there are also lessons to be drawn. The 20th century Structuralist current derives from political nightmare. Durkheim, a French Jew, seeing the deadly Dreyfus conundrum, initiated the 1895 Structuralist revolution, valorising the sociological lifeworld, cause-consequence analysis, and humanist demystification of traditional power. Durkheim's sociology - economies, technologies, organizations, populations, collective norms, and "social imaginings" - emphasized trans-individual structures. Dissolving 19th century Liberal ontological individualism, it remained committed to ethical individualism in human freedom and rights. Durkheim conceived rationality as social, not absolute, while rejecting the reduction of reason to a facet of local culture.

The structuralist revolution, optimistically starting with the democratic Dreyfus resolution, ended so badly, with the Third Reich, and the murder of Marc Bloch 
(Durkheim's heir in historical structuralism) under the Vichy regime. In Graham Greene's The Third Man (1949), the Ferris Wheel in occupied, devastated, and crimeridden post-war Vienna symbolizes the inevitability of evil returns. Anti-modern despair and nostalgia emerged in this spirit, siring a second Structuralist stream, with opposite tendencies: anti-critical, purist, it celebrated traditional lifeworlds as higher existential truth. They were victims of modern science.

The second structuralism was the pioneering deconstructive method of Heidegger's Being and Time (1927), a removal of a thousand years of "Western rationality" to retrieve the "pure sources". Heidegger lent this philosophy to counterEnlightenment in the German aspiration to unique "destiny" under Nazism. The second Structuralism rejected both 19th century Liberal ontological individualism and the ethical individualism underpinning human rights, rejecting the modern equality principle traceable to the French Revolution. Anti-modernism was later embraced in the 1960s French intellectual climate by "Left" intellectuals disgusted with the De Gaulle legacy, the secular Republic, Enlightenment rationality, colonialism, and Communist state-building, collapsing them into one unified "Western" impulse called "modernity". This article has underlined the difference between these two waves of Structuralism, which are too frequently confused. Rules of labour should not be fixed by antecedent "cosmic" tradition. If labour is a religious problem, human will does not change it. Only divine grace does. Here, Selvon, MacInnes, and, before either of them, Rhys, broke with the Second Heideggerian "purist" wave in favour of the original "relational" Structuralism, and championed universal humanism in multi-culturalism.

\section{References}

Dante, Alighieri (2018). Dante's Inferno (Illustrated by Dore). Amazon.

Durkheim, Emile (2009). Les regles de la methode sociologique. Flammarion.

Eddo-Lodge, Reni (2018). Why I'm No Longer Talking to White People About Race. Bloomsbury.

Eliot, T.S. (2016). The Waste Land. Wisehouse.

Foucault, Michel (1980) Power/Knowledge: Selected Interviews and Other Writings 19721977. Pantheon.

Foucault, Michel (1966). Les Mots et les Choses. Gallimard. 
Foucault, Michel. (2000). Ethics: Essential Works of Foucault 1954-1984. Penguin.

Habila, Helon (2007). Out of the Shadows. Guardian March 17.

Heilbroner, Robert L. (1985). The Nature and Logic of Capitalism. Norton.

Jordison, Sam (2018). How the Lonely Londoners extends the novel's language. Guardian October 16.

Kershaw, Ian (2005). Europe's Second Thirty Years War. History Today. Vol. 55, Issue 9, September.

Kolbert, Elizabeth (2018). There's No Scientific Basis for Race - it's a Made Up Label. National Geographic March 12.

Marlowe, Christopher (1998). Dr Faustus. Pennsylvania State University.

McLuhan, Marshall (1964). Understanding Media: the Extensions of Man. Signet.

MacInnes, Colin (2011). Absolute Beginners. Allison and Busby.

Nasta, Susheila (2018). The Lonely Londoners: a new way of reading and writing the city. https://www.bl.uk/windrush/articles/the-lonely-londoners-a-new-way-ofreading-and-writing-the-city

Otele, Olivette (2020). African Europeans. An Untold History. Hurst and Company.

Ove, Horace (1969). Baldwin's Nigger (documentary).

Piketty, Thomas (2013). Le Capital au XXIe siecle. Points.

Rhys, Jean (2000). Voyage in the Dark. Penguin.

Rutherford, Jonathan, (Ed). (1990). Identity: Community, Culture, Difference. Lawrence and Wishart.

Saussure, Ferdinand de (2005). Cours de linguistique generale. Payot.

Selvon, Sam (2006). The Lonely Londoners. Penguin.

Wills, Clair (2017). Lovers and Strangers. An Immigrant History of Post-War Britain. Penguin.

Handling Editor:

Stan Bogdanov, PhD

New Bulgarian University 